REGULATING SEX IN

THE ROMAN EMPIRE 


\section{$\longrightarrow$ \\ STNKRISIS \\ Comparative Approaches to Early Christianity in Greco-Roman Culture}

SERIES EDITORS

\section{Dale B. Martin (Yale University) and L. L. Welborn (Fordham University)}

Synkrisis is a project that invites scholars of early Christianity and the Greco-Roman world to collaborate toward the goal of rigorous comparison. Each volume in the series provides immersion in an aspect of Greco-Roman culture, so as to make possible a comparison of the controlling logics that emerge from the discourses of GrecoRoman and early Christian writers. In contrast to older "history of religions" approaches, which looked for similarities between religions in order to posit relations of influence and dependency, Synkrisis embraces a fuller conception of the complexities of culture, viewing Greco-Roman religions and early Christianity as members of a comparative class. The differential comparisons promoted by Synkrisis may serve to refine and correct the theoretical and historical models employed by scholars who seek to understand and interpret the Greco-Roman world. With its allusion to the rhetorical exercises of the Greco-Roman world, the series title recognizes that the comparative enterprise is a construction of the scholar's mind and serves the scholar's theoretical interests.

\section{EDITORIAL BOARD}

Loveday Alexander (Sheffield University)

John Bodel (Brown University)

Kimberly Bowes (University of Pennsylvania)

Daniel Boyarin (University of California, Berkeley)

Fritz Graf (Ohio State University)

Ronald F. Hock (University of Southern California)

Hans-Josef Klauck (University of Chicago)

Angela Standhartinger (Marburg University)

Stanley K. Stowers (Brown University) 


\title{
REGULATING SEX IN
}

\section{THE ROMAN EMPIRE}

\author{
$\longrightarrow$ \\ IDEOLOGY, THE BIBLE, AND \\ THE EARLY CHRISTIANS
}

David Wheeler-Reed

Yale

UNIVERSITY PRESS

New Haven \& London 
Published with assistance from the foundation established in memory of Henry Weldon Barnes of the Class of 1882, Yale College.

Copyright (C) 2017 by Yale University.

All rights reserved.

This book may not be reproduced, in whole or in part, including illustrations, in any form (beyond that copying permitted by Sections 107 and 108 of the U.S. Copyright Law and except by reviewers for the public press), without written permission from the publishers.

Yale University Press books may be purchased in quantity for educational, business, or promotional use.

For information, please e-mail sales.press@yale.edu

(U.S. office) or sales@yaleup.co.uk (U.K. office).

Set in Baskerville and Bulmer type by IDS Infotech Ltd., Chandigarh, India.

Printed in the United States of America.

Library of Congress Control Number: 2017936735

ISBN 978-0-300-22772-7 (hardcover : alk. paper)

A catalogue record for this book is available from the British Library.

This paper meets the requirements of ANSI/NISO

Z39.48-1992 (Permanence of Paper).

10987654321 
For Fitz, without whom none of this would've been possible 
This page intentionally left blank 